\title{
メチロールフェノールのロジン変性作用 678.632'32'21:668.472
}

\section{Rosin Modifying Property of Methylolphenol}

\author{
大田 登* 大 熊 純 一* \\ OOTA Noboru OoKUMA Jun-ichi
}

\section{要旨}

石炭酸とホルムアルデヒドのアルカリ縮合に際し生 成する 6 種のメチロールフェノールについてアビェチ ン酸あるいはロジンの軟化点を高める作用および炭化 水素溶剤に対する溶解性を低める作用をしらべ， 2,4 , 6-トリメチロールフェノールと $3,3^{\prime}, 5,5^{\prime}$-テトラメチ ロールー4, $4^{\prime}$-ジオキシジフェニルメタンは炭化水素に 対する溶解性を減ずる作用は強いが軟化点増加作用が 非常に優れていて, ロジン変性用として最適のもので あることを知つた。

\section{1. 緒言}

ロジン変性フェノール樹脂は油不溶性のフェノール 樹脂をロジンとの溶融によって乾性油可溶性にしたも ので，これをロジンの側からいえばその塗料用として の品質をフェノール樹脂によって改良したものである。 したがってこの目的のフェノール樹脂として適当な縮 合度のものとされているフェノールアルコールについ てロジン変性作用を比較, 検討することは工業上必要 であつて,またそれは $p$-置換フェノールからのフェノ ールアルコールについては乾性油変性作用の検討と関 連させて古くから行われている1)。石炭酸からのフェ ノールアルコールはしかし混合物が多量に変性樹脂に 用いられているにもかかわらずこの作用の検討が行わ れていないのでこの目的の研究を行った。

本報では石炭酸とホルムアルデヒドの縮合に際して 生成する 6 種のメチロールフェノール执よび 6 種の置 換メチロールフェノールについてそれらのアビェチン 酸あるあるいロジンの軟化点拉よび炭化水素溶解性に 及ぼす作用を試験して得た結果を報告する。

\section{2. 実験}

A) 原 料

4ーメチロールフェノール $p$-オキシ安息香酸メチル

*日本ペイント株式会社

[8] 20
エステルをアセチル化した後りチウムアルミニウム水 素化物で還元し2)，ベンゼンから再結晶した。 mp 109 $\sim 110^{\circ}$ 。

2,6-ジメチロルフェノール 瀬戸らの方法3)により 合成し，ベンゼン，クロロホルム拈よび酢酸エチルか ら再結晶した。 $\mathrm{mp} 99 \sim 100^{\circ}$ 。

2,4-ジメチロールフェノール Reeze の方法4によ つて合成し,䣫酸エチルから再結晶した。 $\mathrm{mp} 94 \sim 95^{\circ}$ 。

2,4,6-トリメチロールフェノール Freeman の方 法 ${ }^{2}$ によって石炭酸ホルムアルデヒド反応生成物から 分離し, 酢酸エチルから再結晶した。mp 90〜91。 2,4-ジメチロールー6-メチルフエノール Granger の 方法5゙より合成し，クロロホルムから再結晶した。 mp 93 $94^{\circ}$ 。

$3,3^{\prime}$-ジメチロールー2, $2^{\prime}$-ジオキシー $5,5^{\prime}$-ジメチルジ フェニルメタン Morgan 法6) によって 2,2'-ジオキ シー5, 5'-ジメチルジフェニルメタンを得, Köbner法7) によって合成し，トルオールから再結晶した。

2,6-ビス（3-メチロール-2-オキシ-5-メチルベンジ ル)ー4ーメチルフェノール 同様 Morgan 法6に炕つて 2, 6-ビス(2-オキシー5-メチルベンジル)-4-メチルフェ ノールを得, Köbner 法7によつて合成し、ベゾール から再結晶した。

2-メチロールフェノール，3，3'，5，5'-テトラメチロ ールー4, 4'-ジオキシジフェニルメタン，2-メチロール -4-メチルフエノール，2,6-ジメチロール-4-メチルフ エノール，2-メチロールー4, 6-ジメチルフエノー拈 びアビエチン酸 著者の一人による別報8,9) と同様の ものを用いた。

ロジン 市販香港ロジン, 色相 WW, 軟化点 $58.5^{\circ}$, 酸価 165.7 。

\section{B 変性物試料の製法}

フェノーアルコールーアビエチン酸の溶融物フェ ノールアルコール類 0.002 あるいは 0.004 フェノー ル当量 $\mathrm{mol}(0.248 \sim 0.736 \mathrm{~g})$, アビェチン酸 $0.01 \mathrm{~mol}$ $(3.02 \mathrm{~g})$ を $15 \mathrm{cc}$ クライゼンフラスコに入れ, 反応を 
平滑に行わすために $n$ ーブタノール $3 \mathrm{cc}$ を加えて機峨 的にかきまぜながら窒素の気流下で約 40 分を要して 浴温が $225^{\circ}$ になるまで加熱した。

ロジン変性樹脂 フェノールアルコール 0.003 フェ
ノール当量 mol $(0.369 \sim 0.552 \mathrm{~g})$ あるいはその 2 倍 量, ロジン $4 \mathrm{~g} を 15 \mathrm{cc}$ フラスコ中でブタノール $2 \mathrm{cc}$ の添加下浴温が $255^{\circ}$ になるまで徐々に加熱し，つい でその生成物にグリセリン $0.48 \mathrm{~g}$ を加えて再び加熱

表 1 メチロールフェノール類一アビエチン酸溶融物の試験結果

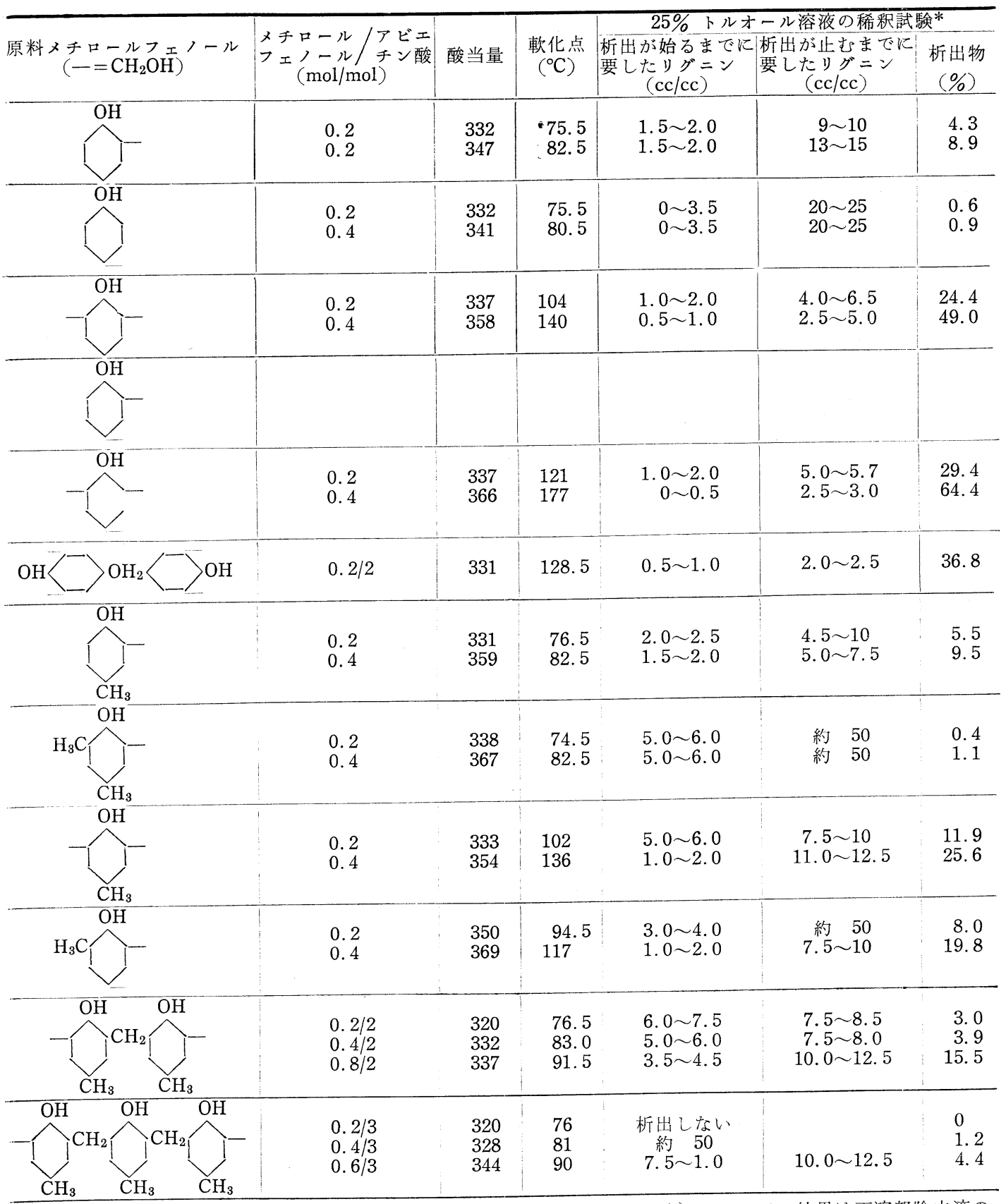

*4一メチールフェノールによる加熱物（不透明でトルオールに一部不溶）についての結果は不溶部除去液の 清澄液についてのものである。 
表 2 ロジン变性フェノール樹脂の試験結果

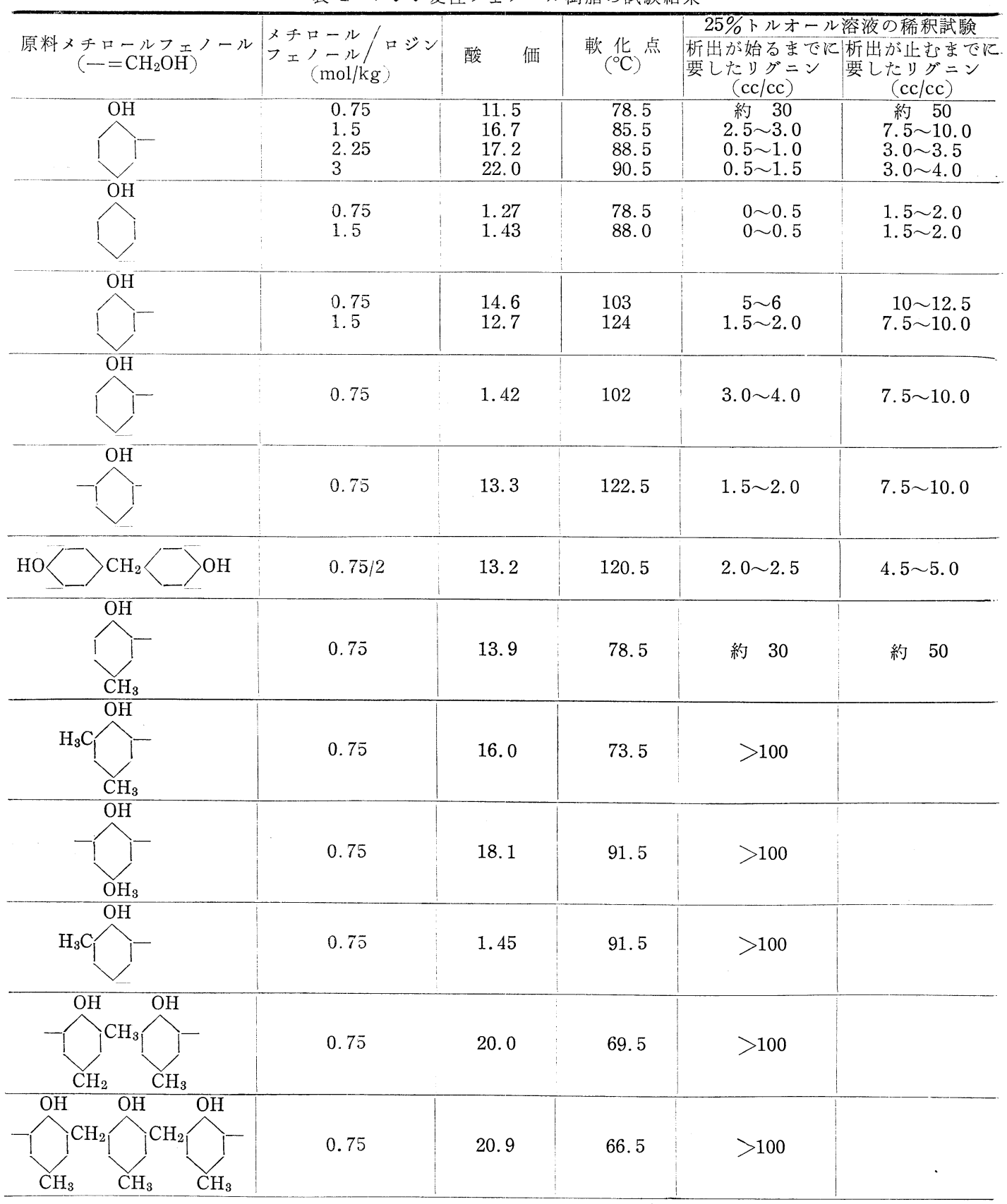

し， $275^{\circ}$ と $280^{\circ}$ に各 2 時間保ってェステル化した。

C）変性物の試験方法

軟化点 毛細管法により試料粉末が透明になるとき の温度を用いた。

炭化水素溶剂に対する溶解性 試料 $0.1 \mathrm{~g}$ をトルオ ール $0.3 \mathrm{cc}$ に溶かし，この溶液（25\% 溶液）にリグ
ロインを 10２0 分の間を扣いてまず $0.2 \mathrm{cc}$ づつ 30 回，つぎに $2 \mathrm{cc}$ づつ 7 回，最後に $10 \mathrm{cc}$ づつ 2 回加 えて析出物の生ずる時期を観察した。フェノールアル コールアビェチン酸溶融物についてはさらに希釈後の 析出物を予じめ科量して扣いた石綿をつめた微量口斗 に集め, $80^{\circ} \mathrm{C}$ で 1 時間乾燥後科量して測定した。 


\section{3. 結果}

実験結果はフェノールアルコールーアビェチン酸溶 融物では表 I, ロジン変性樹脂では表 2 の通りであっ た。

表 1,2 から判るように無置換フェノールアルコー ルアビエチン酸女るいはロジンの軟化点を高める作 用*は メチロールフェノールよりもジメチロールフェノール が勝り, ジメチロールフェノールの作用は $p$-置換ジメ チロールフェノール中その作用の最も優れている $2,6-$ ジメチロールー4ーメチルフェノールよりやや勝る程度 であり, トリメチロールフェノールとテトラメチロー ル 2 核体の作用はジメチロールフェノールよりさらに 著しく優れている。したがってトリメチロールフェノ ールとテトラメチロール 2 核体は何らかの特別の欠点 なければロジン変性フェノール樹脂用のフェノールフ オルムアルデヒド縮合物として最も優れたものと認め られる。

また無置換フエノールアルコールのアビエチン酸あ るいはロジンの溶解性を低める作用は同様表 1,2 に 見られるよ5に一般に $p$-メチル置換フェノールアル コールより大きく，またメチロール化度の高いものほ

*) 2 核体についてはフェノール基 2 ケを有するか らその $1 / 2$ をつて比較した。

(343 頁から続く)

3) S. Van der Meer, Kunststoffe, 37.4(14197)

4) 大田, 昭和 31 年 11 月色材協会研究発表会講演 有合化投稿中

5) F. Ullman, K. Brittner, Ber., 42, 2539(1909)

6) L. L. Stelle, J. Am. Chem. Soc., 44, 1333 (1922)

7) T. T. Webb et al., J. Org. Chem., 4, 389 (1939)

8) J. I. Cunneen et al., J. Chem. Soc., 472

\section{学協会のイ ス}

昭和 32 年秋になつてから色材協会の事務所は東京 神田の塗肘ビル内の新事務室に移転した。事務所は約 10 人の会議に十分な机とイスとが準備されていて, 毎 月定期的に理事会や各種の委員会が開かれている。以 前麻布虎の門田村町と塗料会館に同居していた当时に 比較して一応の拡充整備がはかられたわけである。会 議のできる協会事務所は誠に便利なものである。本年 当初編集委員会のもり，ある報文が問題になつたこと がある。問題というのは辞句や図表がそのままでは本 誌に載せられないからであった。検討また検討ふと小
ど大さい。しかしこの作用はトリメチロールおよびテ トラメチロール 2 核体の場合もロジン変性樹脂の原料 としての使用に支障を与えるようなものではない。

実験結果からはな拈 $p$-置換フェノールアルコール のロジンの軟化点を高める作用が縮合度を高めると減 ずること ${ }^{1)}$ と対応して 2,6 -ジメチロール--4-メチルフ エノールに較べて $p$-メチル犆換のジメチロール 2 核 体与よび 3 核体のその作用はフェノール当量モル当り の作用として小さいことが認められる。しかし表 1 , 2 を対比すれば判るように軟化点の誤差がかなり大き いために期待したメチロール基やメチル置換の位犆の この作用に及ぼす影響は明らかになつていない。

(昭和 32 年 11 月色材協会研究発会講演)

$$
\text { 文献 }
$$

1) H. Hönel, J. Oil \& Colour Chemists' Assoc., 21 (1938)

2) J. H. Freeman, J. Am. Chem. Soc., 74, 6257 (1952)

3）瀬戸，絮内，工化 57,235 (1954)

4) J. Reeze, Angew. Chem., 64, 399 (1952)

5) F. S. Granger, Ind. Eng. Chem., 24, 422: (1932)

6) G. T. Morgan, J. Soc. Chem. Ind., 49, 245 (1930)

7) M. Koebner, Angew. Chem., 46, 251(1933)

8) 大田，有合化投稿中

9) 大田，本誌投稿中

(1943)

9) L. J. Bellamy, The Infra-red Spectra of Complex Molecules p 140 Methuen \& Co. Ltd. London (1956)

10) L. J. Bellamy, ibid. P 100

11) H. Hönel, J. Oil \& Colour Chemists Assoc., 21, 247 (1938)

12）大田, 大熊, 昭和 32 年 11 月色材協会研究発表 講演

生がイスから立ち上ったとたんューチインガム様の粘 着感をシリに受けて木製レザー張りのイスがガタンと した。シリに手を当てて驚いたズボンの一部にスッポ リと小穴があいているではないか。イスの上面にクギ の頭が出ていたからである。

学協会のイスとはこういうものなのだろらか小生以 外にもこんな害を受けた人があるかもしれないがこれ からはイスの表面状態を検べてから腰を下すこととし た。色材協会以外の学協会でもやはり類似の害を受け たこともある。イスのクギは学協会の宿命的存在でな いように願いたいものである。 